ISSN : 2354-6034

IAIN Palangka Raya

\title{
PENGARUH FASHION HIJAB TERHADAP PERILAKU KONSUMTIF MAHASISWI FAKULTAS EKONOMI DAN BISNIS ISLAM IAIN PALANGKA RAYA
}

\author{
Sa'adatunnisa ${ }^{1}$ \\ M. Zainal Arifin, M.Hum ${ }^{2}$ \\ Jelita $^{3}$
}

\begin{abstract}
ABSTRAK
Development of the world fashion at this time theis always increased. It can be demonstrated with the development of fashion hijab at this time. Many models are evolving hijab cause excessive purchasing behavior. Such behavior is the consumer behavior, is behavior that purchase goods or services in excess. For this study will focus on the effect on consumer behavior fashion hijab of student IAIN Palangkaraya to determine the effect on consumer behavior fashion hijab of student IAIN Palangkaraya with technique Product Moment Correlation analysis using SPSS 18.0 version.

This research is a quantitative descriptive research type ex post facto, the authors use the data collection methods of observation and questionnaires. From the test results performed on the instrument 15 respondents with 24 items declared valid question and can be used to collect the data in the study sample. The population in this study are all mahasiwi Faculty of Economics and Business Islam IAIN Palangkaraya, while the sample amounted to 68 respondents student of the Faculty of Economics and Business Islam IAIN Palangkaraya and from the number of respondents were given a questionnaire to be answered. While the technical data analysis techniques used are product moment correlation analysis.
\end{abstract}

Results of research techniques Pearson product moment correlation (r) shows that the correlation between Fashion hijab with the consumer behavior of 0.780 . Based on the interpretation of the correlation coefficient $r$ value, then 0.780 including the level of relations "strong". This shows that there is a strong relationship between fashion hijab with the consumer behavior . Moreover, the significance of the hijab fashion variable $(\mathrm{X})$ and consumer behavior variable $(\mathrm{Y})$ is 0,000 . Based on the decision rules of the hypothesis, the probability value of 0.05 is greater than or equal to the probability value $\mathrm{Sig}$. Or $(0.05 \geq 0.000)$, then Ho is rejected and $\mathrm{Ha}$ accepted, meaning significantly. And the influence of fashion hijab on consumer behavior amounted to $60.9 \%$, while the remaining $39.1 \%$ is influenced by other factors.

Keyword : Fashion Hijab, Consumptive Behavior.

\footnotetext{
${ }^{1}$ Staff Tata Usaha SDN di Kota Palangka Raya

${ }^{2}$ Dosen Fakultas Ekonomi dan Bisnis Islam IAIN Palangka Raya/Lektor.

${ }^{3}$ Dosen Fakultas Ekonomi dan Bisnis Islam IAIN Palangka Raya/Lektor.
} 
ISSN : 2354-6034

IAIN Palangka Raya

\section{A. Latar Belakang Masalah}

Pada zaman dahulu, hijab digunakan sebagai pembeda antara perempuan muslimah dengan yang non muslimah yang merupakan kewajiban setiap muslimah, kemudian digunakan sebagai pembeda antara laki-laki dan perempuan. Sebenarnya perempuan yang menggunakan hijab lebih terlihat sederhana daripada perempuan yang tidak menggunakan hijab.Dan salah satu manfaat dari hijab adalah menghemat pengeluaran dalam berbelanja kebutuhan hijab.

Wanita yang berhijab tidak perlu mengeluarkan banyak uang untuk membeli pakaian dan alat-alat kecantikan.Di sisi lain, wanita yang tidak berhijab akan lebih banyak pengeluarannya dalam hal membeli pakaian dan alat-alat kecantikan. Tujuan dari pengeluaran wanita tidak berhijab dianggap pengeluaran yang berada diluar syariat karena digunakan untuk tujuan kemaksiatan. Karena kebanyakan wanita yang tidak berhijab akan membeli pakaian yang akan mengundang mata laki-laki untuk melihat. ${ }^{4}$

Namun, apabila kita melihat keadaan sekarang khususnya di Indonesia yang mayoritas penduduknya beragama Islam sangat berbeda dengan perbandingan tersebut. Hijab yang digunakan bukan hanya sebagai kewajiban tapi digunakan sebagai gaya hidup juga. Banyak orang yang tidak mengerti akan makna hijab tersebut. Kebanyakan hijab digunakan karena ikut-ikutan trendfashion dan menggunakan hijab karena gaya hidup saja. Mereka melupakan apa makna sebenarnya dari hijab itu. Oleh sebab itu, wanita yang menggunakan hijab terkadang hanya sebagai gaya dan mengikuti trend sehingga mereka menggunakan hijab tidak sesuai dengan syarat-syarat hijab.

Berdasarkanobservasi sementara yang dilakukan penelitidi IAIN Palangka Raya terlihat bahwa sebagian mahasiswi berhijab dengan mengikuti fashion. Mereka menggunakan hijab dengan gaya yang berubah-ubah. Apabila ada gaya terbaru dari hijab, sebagian dari mahasiswi akan mengikuti dan menggunakannya ke kampus IAIN Palangka Raya. ${ }^{5}$ Sebenarnya berhijab dengan mengikuti fashion tidaklah salah namun apabila dalam mengikutinya dilakukan secara berlebihan (dalam pembelian) maka hal itu tidaklah dianjurkan di dalam Islam. ${ }^{6}$

Islam terdapat batasan konsumsi yang diajarkan salah satunya adalah pelarangan israf atau berlebih-lebihan. Perilaku isyrāfdiharamkan sekalipun komoditi yang dibelanjakan adalah halal. Namun demikian, Islam tetap membolehkan seorang Muslim untuk menikmati karunia kehidupan, selama itu masih dalam batas kewajaran. Kehidupan harus dipenuhi secara wajar agar kelangsungan hidup berjalan dengan baik. Namun, apabila kebutuhan hidup itu dipenuhi dengan cara yang berlebih-lebihan, tentu akan menimbulkan efek buruk pada diri manusia tersebut yaitu akan menimbulkan inefisiensi pemanfaatan sumber daya, egoisme ${ }^{7}$,

\footnotetext{
${ }^{4}$ Husein Syahatah, Ekonomi Rumah Tangga Muslim, Jakarta: Gema Insani Press, 1998, hal. 192.

${ }^{5}$ Berdasarkan observasi pada tanggal 17 Maret 2016 di IAIN Palangka Raya.

${ }^{6}$ Apabila itu terjadi terus menerus maka mereka telah melakukan tindakan mengerikan yaitu mubazir.Bahkan dalam surah al-Isra ayat 27, Allah mengatakan bahwa orang-orang yang mubazir merupakan temannnya setan. Bukan hanya itu, hijab yang digunakan juga terkadang tidak sesuai dengan syarat hijab yang dianjurkan. Lihat Abi Jiha, Fiqih Shopping, Jakarta: Zikrul Hakim, 2015, hal. 106.

${ }^{7}$ Tingkah laku yang didasarkan atas dorongan untuk keuntungan diri sendiri.
} 
ISSN : 2354-6034

IAIN Palangka Raya

self-interest $^{8}$, dan tunduknya diri terhadap hawa nafsu sehingga uang yang dibelanjakan hanya habis untuk hal-hal yang tidak perlu dan merugikan diri sendiri. ${ }^{9}$ Larangan isyrāfsecara jelas sudah diterangkan di dalam al-Qur'an yang salah satunya terdapat di dalam surah alAraf ayat $31 .{ }^{10}$

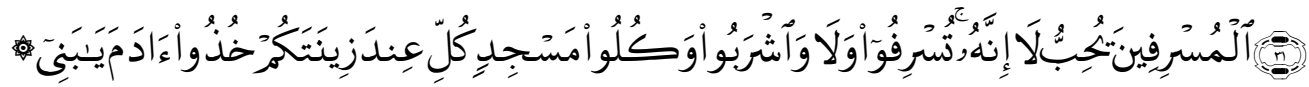

Artinya : "Hai anak Adam, pakailah pakaianmu yang indah di Setiap (memasuki) mesjid, makan dan minumlah, dan janganlah berlebih-lebihan.Sesungguhnya Allah tidak menyukai orang-orang yang berlebih-lebihan."

Berdasarkan fenomena di atas, maka peneliti tertarik meneliti lebih jauh tentang Bagaimana pengaruh fashion hijab terhadap perilaku konsumtif Mahasiswi Fakultas Ekonomi dan Bisnis Islam IAIN Palangka Raya?

\section{B. Deskripsi Teoritik}

1. Fashion dan Hijab

Fashion hijab dapat diartikan sebagai mode dalam menggunakan hijab. Maksudnya adalah perempuan muslimah yang menggunakan hijab yang mengikuti tren atau gaya berhijab modern dapat dikatakan ia mengikuti fashion. Fashion tidak dapat terlepas dari gaya hidup masa kini, begitu pula dengan pemakaian hijab. Namun, kini pemakaian hijab telah berkembang pesat dan sangat berkaitan dengan unsur fashion. Pemakaian hijab yang dulu hanya digunakan sebagai identitas agama bagi muslimah, sekarang telah melebur menjadi sebuah gaya hidup bagi masyarakat muslimah modern yang menjadikan hijab sebagai bagian untuk menunjukkan identitas diri atau konsep diri dalam kehidupan sosial. ${ }^{11}$

Identitas diri yang dimaksud adalah identitas yang membedakan seseorang sebagai individu yang berbeda. Apabila dihubungkan dengan fashion maka menurut Malcolm Barnard bahwa pakaian digunakan untuk menunjukkan nilai sosial atau status, dan orang sering membuat penilaian terhadap nilai sosial, berdasarkan atas apa yang dipakai oleh orang lain tersebut. ${ }^{12}$

2. Perilaku Konsumtif dalam Islam

\footnotetext{
${ }^{8}$ Kepentingan diri sendiri.

${ }^{9}$ Muhammad Muflih, Perilaku Konsumen Dalam Perspektif Ilmu Ekonomi Islam, Jakarta: PT RajaGrafindo Persada, 2006, hal. 15-16.

${ }^{10}$ Departemen Agama RI, Al-Qur'an Dan Terjemahannya,......, hal. 207.

${ }^{11}$ Ade Nur Istiani, Kontruksi Makna Hijab Fashion Bagi Moslem Fashion Blogger, http://jurnal.unpad.ac.id/jkk/article/.../3396, diakses pada tanggal 10 Maret 2016.

${ }^{12}$ Malcolm Barnard, Fashion Sebagai Komunikasi: Cara Mengkomunikasikan Identitas Sosial, Seksual, Kelas Dan Gender, .......,hal.69.
} 
ISSN : 2354-6034

IAIN Palangka Raya

Perilaku konsumtif adalah perilaku yang membelanjakan hartanya untuk hal-hal yang tidak berguna dan berlebih-lebihan. Perilaku ini berhubungan dengan hidup yang tabdzir danisyrāf, dan ini tidak dibenarkan di dalam ekonomi Islam. Islam memberikan sikap yang tegas untuk perilaku konsumtif, salah satunya adalah pelarangan terhadap sesuatu yang berlebihan yang tidak mendatangkan manfaat dan pelarangan ini disebutkan di dalam Al-Qur'an Surah al-Isra ayat 26-27: $:^{13}$

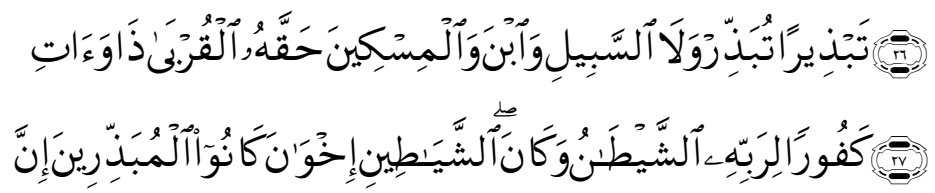

Artinya : " Dan berikanlah kepada keluarga-keluarga yang dekat akan haknya, kepada orang miskin dan orang yang dalam perjalanan dan janganlah kamu menghambur-hamburkan (hartamu) secara boros. Sesungguhnya pemborospemboros itu adalah saudara-saudara syaitan dan syaitan itu adalah sangat ingkar kepada Tuhannya."

Tabzir adalah sesuatu yang ditentang oleh Islam, hal ini terbukti dengan arti dari surah diatas orang-orang yang pemboros adalah saudara setan. Tabzir lebih kepada sifat pemborosan. Menurut Muhammad Hasan al-Hamshi, pemborosan itu sangat terkait dengan kadar ketaatan kita kepada Allah. Semakin boros seseorang maka semakin lemah tingkat ketaatannya kepada Allah. Berarti bahwa orang yang boros berada dalam jalan yang sama terhadap setan. Keduanya berada pada jalur pembangkangan kepada Allah. Imam Syafi' i memberikan pernyataan bahwa tabzir adalah membelanjakan harta untuk sesuatu yang tidak dibenarkan. Jumhur ulama berpendapat bahwa di dalam hal kebaikan tidak ada istilah mubadzir. Akan tetapi, barang siapa yang membeanjakan hartanya demi nafsu belaka dan melebihi kebutuhannya sampai hartanya habis, maka ia termasuk kategori pemboros. ${ }^{14}$

Dikatakan boros apabila dalam pemenuhan kebutuhan sehari-hari di luar batas kewajaran. Yaitu berlebih-lebihan dalam hal makanan, berpakaian, membangun rumah, dan pemenuhan hiburan. Jadi, jika seseorang membelanjakan hartanya untuk kehidupan hidupnya secara layak, maka ia tidak termasuk orang-orang yang boros.

Selain perilaku boros yang sudah dijelaskan sebelumnya, ada juga perilaku konsumtif yang lain yaituisyrāf. Perilaku ini mempunyai kesamaan dengan perilaku Tabzir, samasama perilaku yang berlebih-lebihan dalam hal konsumsi, namun perilaku Isyrāf lebih kepada bermewah-mewah. Kemewahan merupakan sifat utama penduduk neraka, kemegahan dalam pandangan Islam merupakan faktor utama dari kerusakan maupun kehancuraan individu dan masyarakat. Menurut Imam al-Razi, orang yang mewah adalah yang sombong karena kenikmatan dan kemudahan hidup. Tidak boleh berlebih-lebihan dalam membelanjakan hartanya walaupun di jalan yang halal. Rasulullah bahkan

\footnotetext{
${ }^{13}$ Departemen Agama RI, Al-Qur'an Dan Terjemahannya,....., hal. 388.

${ }^{14}$ Ika Yunia Fauzia dan Abdul Kadir Riyadi, Prinsip dasar Ekonomi Islam Perspektif Maqashid AlSyariah,....., hal. 188 .
} 
ISSN : 2354-6034

IAIN Palangka Raya

melarang seorang sahabat untuk berlebih-lebihan ketia sedang berwudhu walaupun hanya dengan menggunakan air sungai yang mengalir. ${ }^{15}$

Akan tetapi, tidak ada larangan bagi seorang Muslim untuk bersenang-senang dan membelanjakan uangnya untuk kehidupan duniawi. Selama hal tersebut tidak melampaui batas yang mengakibatkan pada pemborosan.

\section{Pembahasan}

\section{Penyajian Data}

2.

Penelitian ini memiliki dua variabel yaitu fashion hijab sebagai variabel $\mathrm{X}$ dan perilaku konsumtif sebagai variabel Y yang bertujuan untuk mengetahui derajat hubungan dan kontribusi variabel X terhadap variabel Y, maka teknik yang digunakan adalah teknik analisis Korelasi Pearson Product Moment (r) dengan menggunakan program SPSS 18.0. Dan dari hasil penelitian yang dilakukan, maka diperoleh data sebagai berikut :

\section{a. Penyajian Data Fashion Hijab}

Tabel 4.1

Distribusi Frekuensi Pendapat Responden Terhadap Fashion Hijab

\begin{tabular}{|c|c|c|c|c|c|c|c|c|c|c|c|c|}
\hline \multirow{2}{*}{ NO } & \multicolumn{2}{|c|}{ SS } & \multicolumn{3}{|c|}{ S } & \multicolumn{2}{|c|}{ N } & \multicolumn{2}{|c|}{ TS } & \multicolumn{2}{|c|}{ STS } & \multicolumn{2}{c|}{ TOTAL } \\
\cline { 2 - 14 } & $\mathbf{F}$ & $\%$ & $\mathbf{F}$ & $\%$ & $\mathbf{F}$ & $\%$ & $\mathbf{F}$ & $\%$ & $\mathbf{F}$ & $\%$ & $\mathbf{F}$ & $\%$ \\
\hline 1 & 15 & 22,1 & 18 & 26,47 & 26 & 38,2 & 7 & 10,3 & 2 & 2,94 & 68 & 100 \\
\hline 2 & 4 & 5,88 & 17 & 25 & 24 & 35,3 & 19 & 27,9 & 4 & 5,88 & 68 & 100 \\
\hline 3 & 8 & 11,8 & 38 & 55,88 & 19 & 27,9 & - & - & 3 & 4,41 & 68 & 100 \\
\hline 4 & 4 & 5,88 & 10 & 14,71 & 34 & 50 & 17 & 25 & 3 & 4,41 & 68 & 100 \\
\hline 5 & 2 & 2,94 & 18 & 26,47 & 23 & 33,8 & 20 & 29,4 & 5 & 7,35 & 68 & 100 \\
\hline 6 & 1 & 1,47 & 3 & 4,41 & 32 & 47,1 & 23 & 33,8 & 9 & 13,2 & 68 & 100 \\
\hline 7 & - & - & 8 & 11,76 & 21 & 30,9 & 30 & 44,1 & 9 & 13,2 & 68 & 100 \\
\hline 8 & 34 & 50 & 20 & 29,41 & 12 & 17,6 & 1 & 1,47 & 1 & 1,47 & 68 & 100 \\
\hline 9 & - & - & 3 & 4,41 & 33 & 48,5 & 24 & 35,3 & 8 & 11,8 & 68 & 100 \\
\hline 10 & 3 & 4,41 & 30 & 44,12 & 33 & 48,5 & 2 & 2,94 & - & - & 68 & 100 \\
\hline 11 & 11 & 16,2 & 18 & 26,47 & 29 & 42,6 & 9 & 13,2 & 1 & 1,47 & 68 & 100 \\
\hline 12 & 4 & 5,88 & 18 & 26,47 & 31 & 45,6 & 11 & 16,2 & 4 & 5,88 & 68 & 100 \\
\hline
\end{tabular}

Tabel diatas menunjukkan hasil jawaban kuesioner yang diperoleh dari 68 responden mahasisiwi IAIN Palangka Raya Fakultas Ekonomi dan Bisnis Islam.(Lihat: Lampiran 1)

Tabel 4.2

Tabulasi Data Fashion Hijab

\footnotetext{
${ }^{15}$ Ika Yunia Fauzia, Prinsip dasar Ekonomi Islam Perspektif Maqashid Al-Syariah,....., hal.190-191
} 


\begin{tabular}{|c|c|c|c|c|c|c|c|c|c|c|c|c|c|c|}
\hline \multirow{2}{*}{ NO } & \multicolumn{12}{|c|}{ PERTANYAAN } & \multirow{2}{*}{$\Sigma$} & \multirow{2}{*}{$\begin{array}{l}\text { RATA- } \\
\text { RATA }\end{array}$} \\
\hline & 1 & 2 & 3 & 4 & 5 & 6 & 7 & 8 & 9 & 10 & 11 & 12 & & \\
\hline 1 & 5 & 4 & 4 & 4 & 3 & $\Delta$ & 4 & 4 & 3 & 3 & 4 & 4 & 46 & 3,83 \\
\hline 2 & 4 & 4 & 4 & 3 & 4 & 3 & 3 & & 3 & 3 & 5 & 5 & 45 & 3,75 \\
\hline 3 & 5 & 4 & 3 & 3 & 3 & & 1 & 3 & 3 & 3 & 4 & 3 & 37 & 3,08 \\
\hline 4 & 4 & 3 & 4 & 4 & 3 & & 4 & & 3 & 4 & 4 & 4 & 44 & 3,67 \\
\hline 5 & 5 & 4 & 5 & 4 & 4 & & 2 & & 2 & 4 & 4 & 4 & 45 & 3,75 \\
\hline 6 & 5 & 4 & 4 & 3 & 3 & & 2 & & 3 & 3 & 5 & 4 & 43 & 3,58 \\
\hline 7 & 3 & 2 & 4 & 2 & 4 & 2 & 2 & 5 & 1 & 5 & 3 & 3 & 36 & 3 \\
\hline 8 & 3 & 4 & 5 & 4 & 4 & & 4 & 5 & 2 & 5 & 5 & 3 & 46 & 3,83 \\
\hline 9 & 4 & 4 & 4 & 3 & 4 & 3 & 3 & 5 & 3 & 3 & 4 & & 44 & 3,67 \\
\hline 10 & 4 & 4 & 4 & 4 & 4 & 4 & 3 & 5 & 4 & 4 & 5 & 4 & 49 & 4,08 \\
\hline 11 & 5 & 4 & 3 & 4 & 5 & 3 & 3 & 5 & 3 & 5 & 5 & 4 & 49 & 4,08 \\
\hline 12 & 5 & 4 & 5 & 4 & 3 & 3 & 2 & 5 & 3 & 4 & 4 & 5 & 47 & 3,92 \\
\hline 13 & 3 & 3 & 4 & 3 & 3 & 3 & 3 & 4 & 3 & 3 & 3 & 3 & 38 & 3,17 \\
\hline 14 & 4 & 4 & 4 & 3 & 3 & 3 & 4 & 4 & 3 & 3 & 3 & 4 & 42 & 3,5 \\
\hline 15 & 4 & 4 & 4 & 2 & 2 & & 3 & 4 & 3 & 3 & 3 & 3 & 37 & 3,08 \\
\hline 16 & 3 & 3 & 3 & 3 & 4 & & 2 & 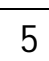 & 4 & 2 & 4 & & 41 & 3,42 \\
\hline 17 & 3 & 3 & 3 & 2 & 3 & & 2 & & 2 & & 3 & & & 2,92 \\
\hline 18 & 5 & 4 & 4 & 3 & 3 & 2 & 2 & 5 & 2 & 4 & 3 & 4 & 41 & 3,42 \\
\hline 19 & 3 & 3 & 4 & 2 & 2 & 3 & 3 & 4 & 3 & 3 & 4 & 4 & 38 & 3,17 \\
\hline 20 & 1 & 1 & 3 & 1 & 2 & 2 & 2 & 4 & 3 & 4 & 3 & 3 & 29 & 2,42 \\
\hline 21 & 5 & 3 & 4 & 3 & 4 & 3 & 2 & 5 & 1 & 4 & 3 & 3 & 40 & 3,33 \\
\hline 22 & 2 & 3 & 4 & 2 & 2 & 2 & 2 & 4 & 2 & 4 & 4 & 4 & 35 & 2,92 \\
\hline 23 & 2 & 2 & 4 & 2 & 1 & 1 & 2 & 4 & 1 & 2 & 3 & 2 & 26 & 2,17 \\
\hline 24 & 3 & 2 & 4 & 2 & 2 & 3 & 2 & 4 & 2 & 3 & 4 & 2 & 33 & 2,75 \\
\hline 25 & 3 & 2 & 4 & 3 & 4 & 5 & 2 & 5 & 3 & 4 & 2 & 5 & 42 & 3,5 \\
\hline 26 & 4 & 2 & 4 & 3 & 2 & 2 & 2 & 2 & 2 & 4 & 3 & 4 & 34 & 2,83 \\
\hline 27 & 3 & 3 & 4 & 3 & 2 & 2 & 2 & 5 & 2 & 3 & 2 & 3 & 34 & 2,83 \\
\hline 28 & 5 & 2 & 4 & 4 & 2 & 2 & 2 & 5 & 2 & 4 & 4 & 3 & 39 & 3,25 \\
\hline 29 & 4 & 3 & 3 & 3 & 2 & 3 & 2 & 4 & 3 & 4 & 4 & 2 & 37 & 3,08 \\
\hline 30 & 5 & 3 & 5 & 5 & 3 & 3 & 3 & 4 & 2 & 3 & 3 & 3 & 42 & 3,5 \\
\hline 31 & 4 & 3 & 4 & 2 & 2 & 1 & 2 & 5 & 1 & 4 & 4 & 4 & 36 & 3 \\
\hline 32 & 3 & 3 & 4 & 2 & 2 & 1 & 2 & 5 & 1 & 4 & 4 & 4 & 35 & 2,92 \\
\hline 33 & 3 & 3 & 3 & 3 & 3 & 3 & 3 & 4 & 2 & 3 & 3 & 2 & 35 & 2,92 \\
\hline 34 & 3 & 2 & 4 & 3 & 3 & 2 & 2 & 3 & 2 & 3 & 3 & 3 & 33 & 2,75 \\
\hline 35 & 3 & 3 & 3 & 3 & 3 & 3 & 3 & 3 & 2 & 3 & 2 & 3 & 34 & 2,83 \\
\hline
\end{tabular}


ISSN : 2354-6034

IAIN Palangka Raya

\begin{tabular}{|c|c|c|c|c|c|c|c|c|c|c|c|c|c|c|}
\hline 36 & 2 & 1 & 1 & 1 & 2 & 2 & 1 & 3 & 2 & 4 & 1 & 1 & 21 & 1,75 \\
\hline 37 & 3 & 4 & 4 & 2 & 2 & 1 & 1 & 4 & 1 & 3 & 3 & 3 & 31 & 2,58 \\
\hline 38 & 5 & 2 & 4 & 3 & 4 & 2 & 2 & 4 & 3 & 4 & 5 & 3 & 41 & 3,42 \\
\hline 39 & 4 & 3 & 3 & 2 & 2 & 2 & 2 & 5 & 2 & 4 & 3 & 2 & 34 & 2,83 \\
\hline 40 & 4 & 4 & 4 & 3 & 3 & 3 & 3 & 3 & 4 & 4 & 3 & 3 & 41 & 3,42 \\
\hline 41 & 4 & 5 & 4 & 5 & 3 & 3 & 2 & 3 & 3 & 3 & 3 & 3 & 41 & 3,42 \\
\hline 42 & 3 & 4 & 5 & 2 & 2 & 2 & 3 & 5 & 3 & 4 & 2 & 4 & 39 & 3,25 \\
\hline 43 & 4 & 2 & 3 & 3 & 2 & 2 & 2 & 5 & 3 & 3 & 3 & 3 & 35 & 2,92 \\
\hline 44 & 5 & 2 & 4 & 2 & 2 & 3 & 2 & 5 & 3 & 3 & 3 & 2 & 36 & 3 \\
\hline 45 & 3 & 2 & 5 & 1 & 1 & 3 & 1 & 5 & 3 & 3 & 2 & 2 & 31 & 2,58 \\
\hline 46 & 5 & 3 & 5 & 3 & 3 & 3 & 2 & 5 & 3 & 3 & 3 & 3 & 41 & 3,42 \\
\hline 47 & 3 & 1 & 4 & 2 & 3 & 1 & 1 & 5 & 2 & 3 & 3 & 2 & 30 & 2,5 \\
\hline 48 & 3 & 2 & 1 & 3 & 4 & 2 & 4 & 5 & 3 & 4 & 5 & 3 & 39 & 3,25 \\
\hline 49 & 3 & 4 & 4 & 5 & 4 & 3 & 4 & 5 & 2 & 4 & 5 & 4 & 47 & 3,92 \\
\hline 50 & 4 & 2 & 4 & 3 & 4 & 2 & 2 & 3 & 2 & 4 & 3 & 2 & 35 & 2,92 \\
\hline 51 & 3 & 2 & 1 & 3 & 1 & 2 & 1 & 1 & 3 & 4 & 2 & 1 & 24 & 2 \\
\hline 52 & 3 & 3 & 3 & 3 & 4 & 3 & 3 & 4 & 3 & 4 & 4 & 3 & 40 & 3,33 \\
\hline 53 & 5 & 2 & 4 & 3 & 3 & 3 & 3 & 3 & 3 & 3 & 4 & 3 & 39 & 3,25 \\
\hline 54 & 3 & 1 & 4 & 3 & 4 & 1 & 1 & 3 & 1 & 4 & 2 & 1 & 28 & 2,33 \\
\hline 55 & 4 & 3 & 4 & 4 & 4 & 3 & 3 & 4 & 3 & 3 & 5 & 4 & 44 & 3,67 \\
\hline 56 & 5 & 5 & 5 & 5 & 2 & 3 & 3 & 5 & 3 & 3 & 5 & 5 & 49 & 4,08 \\
\hline 57 & 3 & 2 & 3 & 2 & 1 & 1 & 1 & 4 & 1 & 4 & 2 & 1 & 25 & 2,08 \\
\hline 58 & 2 & 3 & 3 & 3 & 3 & 3 & 2 & 5 & 3 & 3 & 5 & 2 & 37 & 3,08 \\
\hline 59 & 3 & 3 & 3 & 2 & 1 & 1 & 1 & 5 & 2 & 3 & 3 & 3 & 30 & 2,5 \\
\hline 60 & 1 & 2 & 3 & 2 & 2 & 4 & 3 & 3 & 3 & 3 & 3 & 3 & 32 & 2,67 \\
\hline 61 & 4 & 3 & 3 & 4 & 5 & 3 & 3 & 5 & 3 & 3 & 4 & 3 & 43 & 3,58 \\
\hline 62 & 3 & 3 & 4 & 3 & 4 & 3 & 2 & 5 & 3 & 4 & 2 & 3 & 39 & 3,25 \\
\hline 63 & 4 & 5 & 4 & 3 & 3 & 3 & 3 & 5 & 2 & 3 & 3 & 3 & 41 & 3,42 \\
\hline 64 & 3 & 3 & 4 & 3 & 4 & 2 & 2 & 3 & 2 & 4 & 3 & 3 & 36 & 3 \\
\hline 65 & 2 & 2 & 3 & 3 & 3 & 3 & 3 & 4 & 2 & 3 & 3 & 3 & 34 & 2,83 \\
\hline 66 & 4 & 5 & 4 & 3 & 3 & 3 & 3 & 5 & 2 & 3 & 3 & 3 & 41 & 3,42 \\
\hline 67 & 2 & 3 & 3 & 3 & 3 & 3 & 2 & 5 & 3 & 4 & 4 & 4 & 39 & 3,25 \\
\hline 68 & 2 & 2 & 3 & 3 & 2 & 1 & 2 & 3 & 2 & 4 & 3 & 3 & 30 & 2,5 \\
\hline$\Sigma$ & 241 & 202 & 252 & 199 & 196 & 168 & 164 & 289 & 167 & 238 & 233 & 211 & 2560 & 213 \\
\hline $\begin{array}{l}\text { RATA- } \\
\text { RATA }\end{array}$ & 3,5 & 3 & 3,7 & 2,9 & 2,88 & 2,5 & 2,41 & 4,3 & 2,5 & 3,5 & 3,4 & 3,1 & 37,65 & 3,14 \\
\hline
\end{tabular}

Dari tabel diatas diketahui skor tertinggi sebesar 4,08 dan skor terendah adalah 1,75 kemudian jumlah rata-rata fashion hijab adalah 213 dengan demikian jumlah rata- 
ISSN : 2354-6034

IAIN Palangka Raya

rata skor fashion hijab adalah 213 dibagi dengan jumlah sampel 68 adalah sebesar 3,14 .

Selanjutnya untuk mengetahui pada kualifikasi mana fashion hijab tersebut adalah dengan menggunakan interval yang mempunyai kategori sangat tinggi, tinggi, sedang, rendah dan sangat rendah, perhitungannya adalah sebagai berikut :

Diketahui : Rata-rata skor tertinggi $=4,08$

$$
\begin{aligned}
\mathcal{R} & =\frac{H-L}{5} \\
& =\frac{4,08-1,75}{5}=0,47
\end{aligned}
$$

Dari perhitungan tersebut dapat diperoleh interval :

1. $3,63-4,1=$ Sangat Tinggi

2. $3,16-3,63=$ Tinggi

3. $2,69-3,16=$ Sedang

4. $2,22-2,69=$ Rendah

5. $1,75-2,22=$ Sangat Rendah

\begin{tabular}{|c|c|c|c|c|}
\hline No & Interval & Kategori & $\mathbf{F}$ & $\%$ \\
\hline 1 & $3,63-4,1$ & Sangat Tinggi & 12 & 17,65 \\
\hline 2 & $3,16-3,63$ & Tinggi & 25 & 36,76 \\
\hline 3 & $2,69-3,16$ & Sedang & 20 & 29,41 \\
\hline 4 & $2,22-2,69$ & Rendah & 7 & 10,29 \\
\hline 5 & $1,75-2,22$ & Sangat Rendah & 4 & 5,882 \\
\hline \multicolumn{3}{|c|}{ JUM LAH } & 68 & 100 \\
\hline
\end{tabular}

Tabel 4.3

Data Interval Fashion Hijab

Tabel diatas adalah data interval fashion hijab yang didapatkan dari rata-rata jumlah yang ada di tabulasi data fashion hijab. Langkah selanjutnya adalah menentukan distribusi kategori dari fashion hijab dengan cara jumlah total rata-rata dibagi dengan jumlah responden yaitu sebesar $213: 68=3,13$. Dari hasil yang didapatkan sebesar 3,13 maka fashion hijab termasuk kategori sedang.

\section{b. Penyajian Data Perilaku Konsumtif}

Tabel 4.4 
ISSN : 2354-6034

IAIN Palangka Raya

Distribusi Frekuensi Pendapat Responden Terhadap Perilaku Konsumtif

\begin{tabular}{|c|c|c|c|c|c|c|c|c|c|c|c|c|}
\hline \multirow{2}{*}{ NO } & \multicolumn{2}{|c|}{ SS } & \multicolumn{2}{|r|}{$\mathbf{S}$} & \multicolumn{2}{|r|}{ N } & \multicolumn{2}{|c|}{ TS } & \multicolumn{2}{|c|}{ STS } & \multicolumn{2}{|c|}{ TOTAL } \\
\hline & $\mathbf{F}$ & $\%$ & $F$ & $\%$ & $\mathbf{F}$ & $\%$ & $F$ & $\%$ & $\mathbf{F}$ & $\%$ & $\mathbf{F}$ & $\%$ \\
\hline 1 & 10 & 14,7 & 25 & 36,8 & 26 & 38,24 & 7 & 10,3 & - & - & 68 & 100 \\
\hline 2 & 8 & 11,8 & 25 & 36,8 & 28 & 41,18 & 7 & 10,3 & - & - & 68 & 100 \\
\hline 3 & 9 & 13,2 & 24 & 35,3 & 32 & 47,06 & 3 & 4,41 & - & & 68 & 100 \\
\hline 4 & 12 & 17,6 & 29 & 42,7 & 20 & 29,41 & 7 & 10,3 & - & & 68 & 100 \\
\hline 5 & 5 & 7,35 & 19 & 27,9 & 22 & 32,35 & 15 & 22,1 & 7 & 10,3 & 68 & 100 \\
\hline 6 & 11 & 16,2 & 33 & 48,5 & 15 & 22,06 & 9 & 13,2 & & & 68 & 100 \\
\hline 7 & 4 & 5,88 & 21 & 30,9 & 25 & 36,76 & 18 & 26,5 & - & - & 68 & 100 \\
\hline 8 & 4 & 5,88 & 18 & 26,5 & 39 & 57,35 & 7 & 10,3 & - & - & 68 & 100 \\
\hline 9 & 2 & 2,94 & 13 & 19,1 & 21 & 30,9 & 24 & 35,3 & 8 & 11,8 & 68 & 100 \\
\hline 10 & 4 & 5,88 & 22 & 32,4 & 33 & 48,5 & 8 & 11,8 & 1 & 1,47 & 68 & 100 \\
\hline 11 & 3 & 4,41 & 10 & 14,7 & 29 & 42,6 & 18 & 26,5 & 8 & 11,8 & 68 & 100 \\
\hline 12 & - & - & 12 & 17,6 & 23 & 33,8 & 23 & 33,8 & 10 & 14,7 & 68 & 100 \\
\hline
\end{tabular}

Tabel diatas menunjukkan hasil jawaban kuesioner yang diperoleh dari 68 responden mahasisiwi IAIN Palangka Raya Fakultas Ekonomi dan Bisnis Islam. (Lihat: Lampiran 2)

Tabel 4.5

Tabulasi Data Perilaku Konsumtif

\begin{tabular}{|c|c|c|c|c|c|c|c|c|c|c|c|c|c|c|}
\hline \multirow{2}{*}{ NO } & \multicolumn{12}{|c|}{ PERTANYAAN } & \multirow{2}{*}{$\Sigma$} & \multirow{2}{*}{$\begin{array}{l}\text { RATA- } \\
\text { RATA }\end{array}$} \\
\hline & 1 & 2 & 3 & 4 & 5 & 6 & 7 & 8 & 9 & 10 & 11 & 12 & & \\
\hline 1 & 4 & 4 & 4 & 4 & 4 & 5 & 4 & 4 & 3 & 4 & 3 & 4 & 47 & 3,92 \\
\hline 2 & 5 & 5 & 4 & 4 & 4 & 4 & 4 & 5 & 3 & 4 & 4 & 4 & 50 & 4,17 \\
\hline 3 & 5 & 3 & 3 & 4 & 3 & 4 & 4 & 4 & 3 & 5 & 3 & 4 & 45 & 3,75 \\
\hline 4 & 4 & 4 & 5 & 4 & 4 & 4 & 4 & 4 & 4 & 4 & 5 & 4 & 50 & 4,17 \\
\hline 5 & 4 & 4 & 5 & 4 & 4 & 5 & 4 & 4 & 2 & 4 & 4 & 2 & 46 & 3,83 \\
\hline 6 & 5 & 4 & 3 & 4 & 5 & 4 & 4 & 4 & 4 & 4 & 3 & 3 & 47 & 3,92 \\
\hline 7 & 3 & 4 & 5 & 5 & 3 & 2 & 3 & 3 & 2 & 3 & 3 & 2 & 38 & 3,17 \\
\hline 8 & 4 & 3 & 3 & 2 & 4 & 5 & 3 & 3 & 4 & 3 & 3 & 3 & 40 & 3,33 \\
\hline 9 & 4 & 4 & 4 & 4 & 4 & 5 & 4 & 4 & 3 & 4 & 3 & 3 & 46 & 3,83 \\
\hline 10 & 4 & 4 & 4 & 5 & 4 & 5 & 4 & 4 & 4 & 4 & 4 & 4 & 50 & 4,17 \\
\hline 11 & 5 & 5 & 3 & 5 & 4 & 5 & 3 & 5 & 4 & 3 & 3 & 2 & 47 & 3,92 \\
\hline 12 & 4 & 4 & 3 & 5 & 2 & 3 & 5 & 5 & 3 & 3 & 3 & 4 & 44 & 3,67 \\
\hline 13 & 3 & 3 & 3 & 3 & 2 & 3 & 3 & 3 & 2 & 3 & 3 & 3 & 34 & 2,83 \\
\hline 14 & 4 & 4 & 4 & 4 & 3 & 4 & 4 & 4 & 4 & 4 & 3 & 3 & 45 & 3,75 \\
\hline 15 & 3 & 3 & 4 & 3 & 4 & 4 & 4 & 3 & 4 & 3 & 3 & 3 & 41 & 3,42 \\
\hline
\end{tabular}


ISSN : 2354-6034

IAIN Palangka Raya

\begin{tabular}{|c|c|c|c|c|c|c|c|c|c|c|c|c|c|c|}
\hline 16 & 5 & 4 & 5 & 5 & 5 & 5 & 4 & 3 & 2 & 2 & 2 & 2 & 44 & 3,67 \\
\hline 17 & 5 & 5 & 4 & 2 & 1 & 4 & 2 & 3 & 1 & 3 & 1 & 2 & 33 & 2,75 \\
\hline 18 & 4 & 5 & 3 & 4 & 3 & 4 & 3 & 3 & 2 & 5 & 3 & 3 & 42 & 3,5 \\
\hline 19 & 2 & 4 & 2 & 3 & 2 & 4 & 2 & 4 & 4 & 2 & 3 & 3 & 35 & 2,92 \\
\hline 20 & 3 & 3 & 3 & 3 & 2 & 2 & 4 & 3 & 2 & 3 & 3 & 3 & 34 & 2,83 \\
\hline 21 & 3 & 4 & 3 & 3 & 2 & 4 & 3 & 3 & 2 & 4 & 3 & 3 & 37 & 3,08 \\
\hline 22 & 3 & 4 & 4 & 2 & 3 & 4 & 3 & 3 & 2 & 2 & 2 & 2 & 34 & 2,83 \\
\hline 23 & 3 & 3 & 4 & 4 & 1 & 2 & 2 & 3 & 1 & 3 & 2 & 2 & 30 & 2,5 \\
\hline 24 & 3 & 2 & 2 & 4 & 1 & 3 & 3 & 3 & 3 & 2 & 2 & 1 & 29 & 2,42 \\
\hline 25 & 4 & 3 & 3 & 5 & 4 & 4 & 4 & 5 & 5 & 5 & 5 & 4 & 51 & 4,25 \\
\hline 26 & 5 & 2 & 4 & 4 & 2 & 4 & 2 & 2 & 4 & 4 & 4 & 3 & 40 & 3,33 \\
\hline 27 & 3 & 2 & 4 & 3 & 4 & 3 & 3 & 2 & 2 & 3 & 2 & 4 & 35 & 2,92 \\
\hline 28 & 4 & 3 & 4 & 4 & 3 & 4 & 4 & 4 & 3 & 4 & 4 & 4 & 45 & 3,75 \\
\hline 29 & 4 & 3 & 4 & 4 & 4 & 4 & 2 & 3 & 3 & 2 & 2 & 2 & 37 & 3,08 \\
\hline 30 & 4 & 4 & 3 & 4 & 2 & 4 & 4 & 3 & 4 & 4 & 3 & 2 & 41 & 3,42 \\
\hline 31 & 3 & 4 & 3 & 3 & 1 & 3 & 3 & 3 & 1 & 3 & 1 & 1 & 29 & 2,42 \\
\hline 32 & 3 & 4 & 3 & 3 & 1 & 3 & 3 & 3 & 1 & 3 & 1 & 1 & 29 & 2,42 \\
\hline 33 & 3 & 3 & 3 & 3 & 2 & 3 & 2 & 3 & 2 & 3 & 2 & 3 & 32 & 2,67 \\
\hline 34 & 3 & 3 & 3 & 4 & 4 & 4 & 3 & 3 & 2 & 3 & 2 & 2 & 36 & 3 \\
\hline 35 & 2 & 2 & 3 & 2 & 3 & 3 & 3 & 3 & 3 & 3 & 3 & 3 & 33 & 2,75 \\
\hline 36 & 3 & 3 & 5 & 3 & 2 & 2 & 2 & 2 & 1 & 1 & 1 & 1 & 26 & 2,17 \\
\hline 37 & 4 & 3 & 3 & 3 & 4 & 4 & 2 & 4 & 2 & 3 & 1 & 1 & 34 & 2,83 \\
\hline 38 & 4 & 3 & 3 & 4 & 4 & 4 & 4 & 4 & 3 & 4 & 3 & 3 & 43 & 3,58 \\
\hline 39 & 3 & 3 & 4 & 4 & 4 & 4 & 3 & 3 & 3 & 3 & 3 & 2 & 39 & 3,25 \\
\hline 40 & 4 & 4 & 4 & 3 & 3 & 3 & 4 & 3 & 4 & 3 & 4 & 3 & 42 & 3,33 \\
\hline 41 & 5 & 4 & 5 & 4 & 3 & 4 & 5 & 3 & 3 & 3 & 3 & 3 & 45 & 3,75 \\
\hline 42 & 2 & 4 & 3 & 4 & 1 & 5 & 5 & 4 & 5 & 3 & 2 & 2 & 40 & 3,33 \\
\hline 43 & 4 & 5 & 3 & 3 & 3 & 4 & 3 & 3 & 4 & 5 & 3 & 1 & 41 & 3,42 \\
\hline 44 & 4 & 3 & 3 & 5 & 5 & 5 & 3 & 3 & 3 & 3 & 3 & 2 & 42 & 3,5 \\
\hline 45 & 3 & 3 & 4 & 3 & 5 & 3 & 2 & 2 & 1 & 2 & 2 & 2 & 32 & 2,67 \\
\hline 46 & 5 & 5 & 5 & 3 & 4 & 3 & 3 & 3 & 2 & 4 & 2 & 1 & 40 & 3,33 \\
\hline 47 & 3 & 3 & 3 & 2 & 3 & 2 & 2 & 2 & 2 & 3 & 2 & 1 & 28 & 2,33 \\
\hline 48 & 4 & 5 & 3 & 5 & 3 & 4 & 2 & 4 & 2 & 3 & 4 & 2 & 41 & 3,42 \\
\hline 49 & 3 & 4 & 4 & 4 & 2 & 2 & 4 & 4 & 2 & 3 & 4 & 4 & 40 & 3,33 \\
\hline 50 & 4 & 3 & 3 & 3 & 2 & 4 & 2 & 2 & 3 & 4 & 2 & 2 & 34 & 2,83 \\
\hline 51 & 2 & 2 & 3 & 4 & 1 & 4 & 2 & 3 & 3 & 2 & 1 & 1 & 28 & 2,33 \\
\hline 52 & 2 & 3 & 3 & 4 & 2 & 4 & 3 & 2 & 3 & 3 & 3 & 3 & 35 & 2,92 \\
\hline 53 & 4 & 4 & 5 & 4 & 3 & 3 & 3 & 4 & 2 & 4 & 2 & 2 & 40 & 3,33 \\
\hline 54 & 2 & 4 & 4 & 3 & 3 & 2 & 2 & 3 & 1 & 3 & 1 & 2 & 30 & 2,5 \\
\hline
\end{tabular}


ISSN : 2354-6034

IAIN Palangka Raya

\begin{tabular}{|c|c|c|c|c|c|c|c|c|c|c|c|c|c|c|}
55 & 5 & 4 & 3 & 4 & 4 & 4 & 4 & 4 & 3 & 4 & 4 & 4 & 47 & 3,92 \\
\hline 56 & 3 & 5 & 3 & 5 & 5 & 3 & 5 & 3 & 3 & 4 & 5 & 3 & 47 & 3,92 \\
\hline 57 & 4 & 4 & 4 & 4 & 4 & 3 & 2 & 3 & 2 & 3 & 1 & 1 & 35 & 2,92 \\
\hline 58 & 3 & 3 & 4 & 3 & 3 & 2 & 2 & 3 & 2 & 2 & 2 & 2 & 31 & 2,58 \\
\hline 59 & 3 & 3 & 3 & 3 & 3 & 2 & 2 & 3 & 3 & 3 & 3 & 2 & 33 & 2,75 \\
\hline 60 & 3 & 3 & 3 & 4 & 3 & 4 & 3 & 3 & 4 & 4 & 4 & 4 & 42 & 3,5 \\
\hline 61 & 3 & 3 & 3 & 5 & 2 & 3 & 3 & 3 & 3 & 3 & 3 & 3 & 37 & 3,08 \\
\hline 62 & 4 & 2 & 5 & 2 & 3 & 4 & 2 & 3 & 2 & 3 & 2 & 2 & 34 & 2,83 \\
\hline 63 & 4 & 3 & 4 & 4 & 3 & 5 & 4 & 4 & 2 & 4 & 3 & 3 & 43 & 3,58 \\
\hline 64 & 3 & 2 & 4 & 3 & 3 & 4 & 3 & 3 & 2 & 4 & 3 & 3 & 37 & 3,08 \\
\hline 65 & 3 & 3 & 4 & 5 & 3 & 4 & 3 & 3 & 3 & 3 & 3 & 3 & 40 & 3,33 \\
\hline 66 & 4 & 3 & 4 & 4 & 3 & 5 & 3 & 3 & 2 & 4 & 3 & 3 & 41 & 3,42 \\
\hline 67 & 3 & 4 & 3 & 5 & 2 & 4 & 4 & 3 & 1 & 3 & 2 & 2 & 36 & 3 \\
\hline 68 & 2 & 3 & 2 & 2 & 2 & 4 & 3 & 3 & 2 & 3 & 2 & 2 & 30 & 2,5 \\
\hline $\boldsymbol{\Sigma}$ & 242 & 238 & 243 & 250 & 204 & 250 & 215 & 223 & 181 & 224 & 186 & 173 & 2629 & 219 \\
\hline $\begin{array}{c}\text { RATA- } \\
\text { RATA }\end{array}$ & 3,56 & 3,5 & 3,57 & 3,676 & 3 & 3,68 & 3,16 & 3,28 & 2,662 & 3,29 & 2,74 & 2,54 & 38,7 & 3,22 \\
\hline
\end{tabular}

Dari tabel diatas diketahui skor tertinggi sebesar 4,25 dan skor terendah adalah 2,17 kemudian jumlah rata-rata fashion hijab adalah 219 dengan demikian jumlah ratarata skor fashion hijab adalah 219 dibagi dengan jumlah sampel 68 adalah sebesar 3,22 .

Selanjutnya untuk mengetahui pada kualifikasi mana fashion hijab tersebut adalah dengan menggunakan interval yang mempunyai kategori sangat tinggi, tinggi, sedang, rendah dan sangat rendah, perhitungannya adalah sebagai berikut :

Diketahui : Rata-rata skor tertinggi $=4,25$

$$
\begin{aligned}
\mathcal{R} & =\frac{H-L}{5} \\
& =\frac{4,25-2,17}{5}=0,42
\end{aligned}
$$

Dari perhitungan tersebut dapat diperoleh interval :

1. $3,85-4,27=$ Sangat Tinggi

2. $3,43-3,85=$ Tinggi

3. $3,01-3,43=$ Sedang

4. $2,59-3,01=$ Rendah

5. $2,17-2,59=$ Sangat Rendah

Tabel 4.6

Data Interval Perilaku Konsumtif

\begin{tabular}{|l|l|l|l|l|}
\hline No & Interval & Kategori & F & $\%$ \\
\hline
\end{tabular}


ISSN : 2354-6034

IAIN Palangka Raya

\begin{tabular}{|c|c|c|c|c|}
\hline 1 & $3,85-4,27$ & Sangat Tinggi & 9 & 13,24 \\
\hline 2 & $3,43-3,85$ & Tinggi & 13 & 19,12 \\
\hline 3 & $3,01-3,43$ & Sedang & 19 & 27,94 \\
\hline 4 & $2,59-3,01$ & Rendah & 17 & 25 \\
\hline 5 & $2,17-2,59$ & Sangat Rendah & 10 & 14,71 \\
\hline \multicolumn{3}{|c|}{ JUMLAH } & 68 & 100 \\
\hline
\end{tabular}

Tabel diatas adalah data interval perilaku konsumtif yang didapatkan dari ratarata jumlah yang ada di tabulasi data perilaku konsumtif. Langkah selanjutnya adalah menentukan distribusi kategori dari perilaku konsumtif dengan cara jumlah total ratarata dibagi dengan jumlah responden yaitu sebesar $219: 68=3,22$. Dari hasil yang didapatkan sebesar 3,22, maka perilaku konsumtif termasuk kategori sedang.

\section{Hasil Analisis Data}

Sebelum melakukan analisis datateknik analisis Korelasi Pearson Product Moment (r), terlebih dahulu melakukan normalitas data sebagai berikut :

a. Uji Normalitas Data

Uji Normalitas data digunakan untuk mengetahui apakah data penenelitian berdistribusi normal atau tidak.Uji normalitas data dalam penelitian ini menggunkan teknik One Sample Kolmogorov dan grafik histogram. Adapun kriteria di dalam uji normalitas data adalah apabila signifikansi lebih besar dari 5\% atau 0,05 maka dinyatakan bahwa data tersebut berdistribusi normal, sedangkan apabila signifikansi lebih kecil dari 5\% atau 0,05 maka dinyatakan bahwa data tersebut tidak berdistribusi normal. $^{16}$

Berdasarkan uji normalitas data menggunakan SPSS 18.0 diketahui bahwa nilai signifikansi untuk variabel fashion hijab sebesar 0,845 dan untuk variabel perilaku konsumtif sebesar 0,524. Apabila dibandingkan dengan kriteria dalam uji normalitas data maka dapat disimpulkan nilai signifikansi kedua variabel tersebut lebih dari 5\% atau 0,05 maka dapat dinyatakan berdistribusi normal.

Tabel 4.7

One-Sample Kolmogorov-Smirnov Test

\begin{tabular}{|l|l|r|r|}
\hline \multicolumn{2}{|l|}{} & Fashion Hijab & \multicolumn{1}{|c|}{$\begin{array}{c}\text { Perilaku } \\
\text { Konsumtif }\end{array}$} \\
\hline \multirow{2}{*}{$N$} & 68 & 68 \\
\hline \multirow{2}{*}{ Normal Parameters } & Mean & 37,65 & 38,66 \\
\cline { 2 - 4 } & Std. Deviation & 6,161 & 6,324 \\
\hline \multirow{2}{*}{ Most Extreme Differences } & Absolute &, 074 &, 099 \\
\cline { 2 - 4 } & Positive &, 043 &, 086 \\
\cline { 2 - 5 } & Negative &,- 074 &,- 099 \\
\hline Kolmogorov-Smirnov $Z$ & &, 614 &, 812 \\
\hline
\end{tabular}

${ }^{16}$ Duwi Priyanto, Mandiri Belajar SPSS, ......, hal. 28. 
ISSN : 2354-6034

\begin{tabular}{|l|r|r|}
\hline Asymp. Sig. (2-tailed) &, 845 &, 524 \\
\hline
\end{tabular}

a. Test distribution is Normal.

b. Calculated from data.

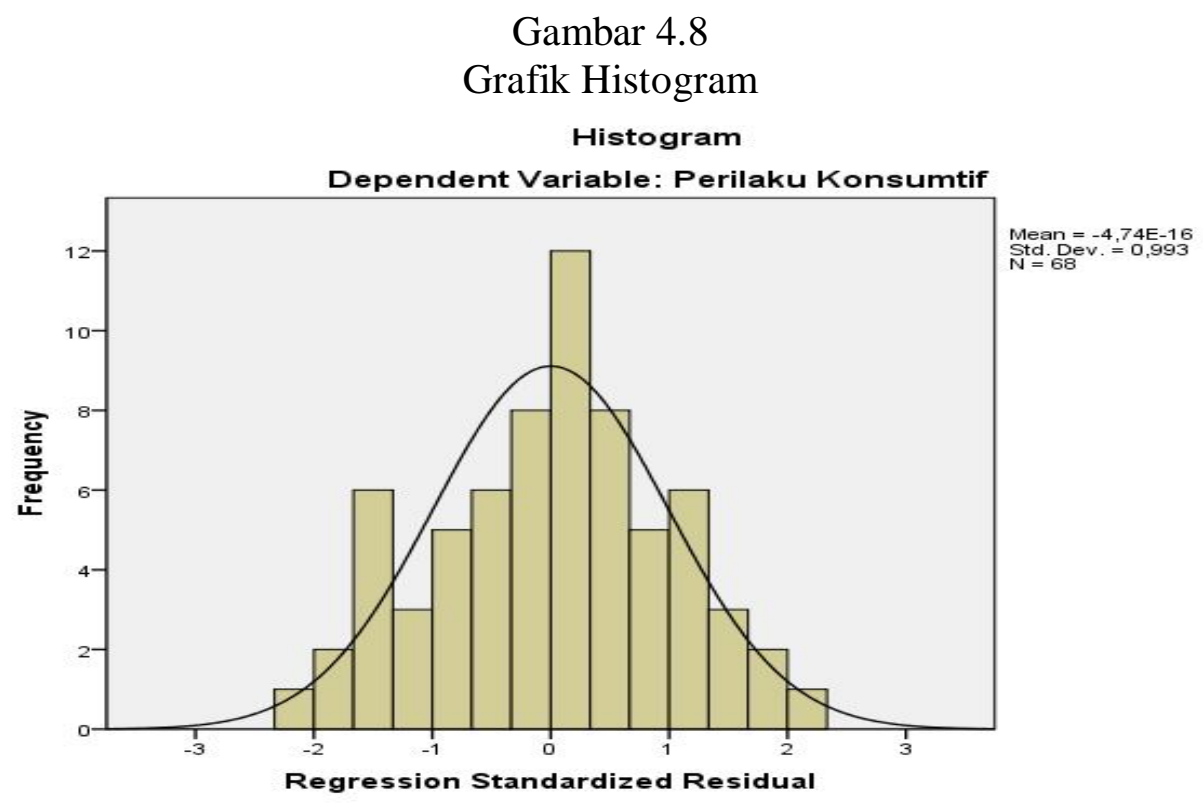

b. Uji Hipotesis

Uji hipotesis ini dilakukan dengan teknik analisis Korelasi Pearson Product Moment (r) yang menggunakan program SPSS 18.0.

Tabel 4.9

Descriptive Statistics

\begin{tabular}{|l|c|c|c|}
\hline & Mean & Std. Deviation & $N$ \\
\hline Fashion Hijab & 37,65 & 6,161 & 68 \\
\hline $\begin{array}{l}\text { Perilaku } \\
\text { Konsumtif }\end{array}$ & 38,66 & 6,324 & 68 \\
\hline
\end{tabular}

Berdasarkan hasil perhitungan yang dilakukan, diketahui hasil deskriptif dari variabel fashion hijab $(\mathrm{X})$ dengan jumlah $\mathrm{N}=68$ responden dengan rata-rata (mean) sebesar 37,65 dan simpangan baku (standar devination) sebesar 6,161. Kemudian, hasil deskriptif dari variabel perilaku konsumtif (Y) dengan jumlah $\mathrm{N}=68$ responden dengan rata-rata (mean) sebesar 38,66 dan simpangan baku (standar devination) sebesar 6,324.

Berdasarkan perhitungan dari tabel 4.11, maka akan diperoleh hasil koefisien korelasi Pearson Product Moment (r) sebagai berikut :

Tabel 4.10

Correlations And Reability

\begin{tabular}{|l|l|r|r|}
\hline \multicolumn{2}{|c|}{} & Fashion Hijab & Perilaku Konsumtif \\
\hline Fashion Hijab & Pearson Correlation & 1 &, $780^{* * *}$ \\
\cline { 2 - 4 } & Sig. (2-tailed) & &, 000 \\
\cline { 2 - 4 } & $N$ & 68 & 68 \\
\hline
\end{tabular}


ISSN : 2354-6034

IAIN Palangka Raya

Reliability Statistics

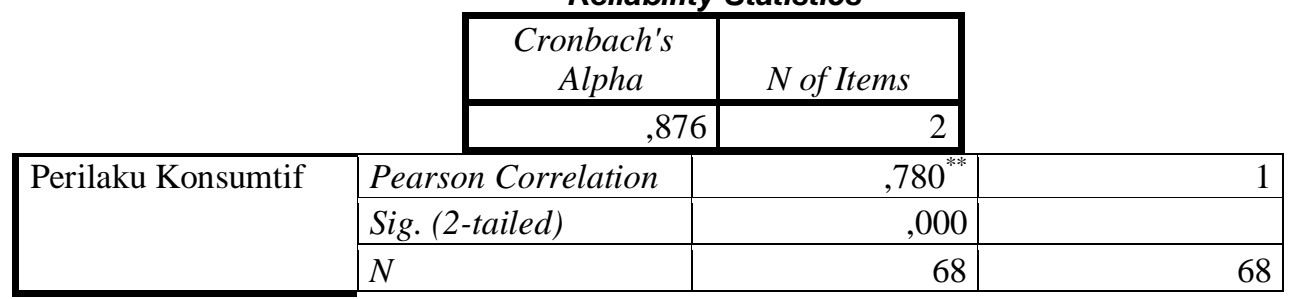

${ }^{* *}$. Correlation is significant at the 0.01 level (2-tailed).

Tabel di atas menunjukkan bahwa korelasi antara Fashion hijab dengan perilaku konsumtif sebesar 0,780.Berdasarkan interprestasi koefisien korelasi nilai $\mathrm{r}$, maka 0,780 termasuk tingkat hubungan "kuat".Hal ini menunjukkan bahwa terjadi hubungan yang kuat antara fashion hijab dengan perilaku konsumtif.Selain itu, pada uji reliabilitas pada dua variabel (fashion hijab dan perilaku konsumtif) diketahui sebesar 0,876. Dan hal ini menunjukkan bahwa dua variabel (fashion hijab dan perilaku konsumtif) dikatakan "sangat andal" menurut tingkat keandalan pada cronbach alpha. Kemudian, apabila nilai reliabilitas dibandingkan dengan nilai tabel $\mathrm{r}$ product moment maka semua data yang dianalisis reliabel dengan $\mathrm{r}=0,876>\mathrm{r}_{\text {tabel }}=$ 0,235 sesuai dengan kaidah keputusan nilai $r>r_{\text {tabel }}$ maka reliabel dan apabila $r<$ $\mathrm{r}_{\text {tabel }}$ maka tidak reliabel.

Untuk menentukan signifikansi dari sebuah hipotesis yang telah dirumuskan, maka diperlukan kaidah keputusan yang akan dijadikan pedoman, sebagai berikut ${ }^{17}$ a. Jika nilai probabilitas 0,05 lebih kecil atau sama dengan nilai probabilitas Sig. Atau $(0,05 \leq \mathrm{Sig})$, maka Ho diterima dan Ha ditolak, artinya tidak signifikan.

b. Jika nilai probabilitas 0,05 lebih besar atau sama dengan nilai probabilitas Sig. Atau ( $0,05 \geq$ Sig ), maka Ho ditolak dan Ha diterima, artinya signifikan.

Hasil analisis diketahui signifikansi antara variabel fashion hijab (X) dan variabel perilaku konsumtif (Y) adalah sebesar 0,000. Berdasarkan kaidah keputusan dari hipotesis, maka nilai probabilitas 0,05 lebih besar atau sama dengan nilai probabilitas Sig. Atau ( $0,05 \geq 0,000$ ), maka Ho ditolak dan Ha diterima, artinya signifikan.Hal ini menunjukkan bahwa adanya pengaruh Fashion Hijab terhadap perilaku konsumtif.

Tabel 4.11

Modal Summary

\begin{tabular}{|c|c|c|c|c|c|}
\hline \multirow{2}{*}{ Model } & \multicolumn{5}{|c|}{ Change Statistics } \\
\cline { 2 - 6 } & $\begin{array}{c}\text { R Square } \\
\text { Change }\end{array}$ & F Change & $d f 1$ & $d f 2$ & $\begin{array}{c}\text { Sig. F } \\
\text { Change }\end{array}$ \\
\hline 1 &, $609^{\mathrm{a}}$ & 102,719 & 1 & 66 &, 000 \\
\hline
\end{tabular}

Hasil penelitian juga menunjukkan bahwa nilai R Square sebesar 0,609 yang dapat diartikan bahwa variabel fashion hijab mempunyai pengaruh sebesar 60,9\%

${ }^{17}$ Riduwan dan Sunarto, Pengantar Statistika Untuk Penelitian: Pendidikan, Sosial, Komunikasi, Ekonomi, dan Bisnis, ..........,hal. 278. 
ISSN : 2354-6034

IAIN Palangka Raya

terhadap variabel perilaku konsumtif, sedangkan 39,1 lainnya dipengaruhi oleh faktor-faktor di luar dari variabel fashion hijab.

\section{Pembahasan}

Menurut Troxell dan Stone, fashion adalah gaya yang diterima dan digunakan oleh mayoritas anggota kelompok dalam satu waktu tertentu. Fashion berkaitan dengan mode atau gaya yang digemari, kepribadian seseorang dan rentang waktu. penutup. Sedangkan hijab adalah penutup, penutup yang dimaksudkan disini adalah pakaian yang menutupi kepala dan seluruh badan. Kemudian, Menurut Lubis, perilaku konsumtif adalah perilaku yang tidak lagi berdasarkan pada pertimbangan yang rasional, melainkan karena adanya keinginan yang sudah mencapai taraf yang sudah tidak rasional lagi.Hijab sebenarnya adalah sebuah kebutuhan primer di kehidupan manusia, namun apabila dalam pembelian hijab sudah berlebihan maka hal itu termasuk ke dalam perilaku konsumtif. Ditambah lagi fashion hijab terus menerus berubah dan hal itu mengakibatkan seseorang akan membeli hijab sesuai dengan tren padahal sebenarnya tidak dibutuhkan. Menurut Kotler, faktor yang mempengaruhi perilaku konsumtif salah satunya adalah gaya hidup. Gaya hidup adalah pola hidup di dunia yang diekspresikan dalam aktivitas, minat dan opini.Gaya hidup juga menggambarkan diri seseorang yang berinteraksi dengan lingkungannya.Yang termasuk dalam gaya hidup adalah fashion.

Berdasarkan teori dan hasil penelitian menunjukkan bahwa antara variabel fashion hijab dengan perilaku konsumtif memang memiliki pengaruh.Sehingga, salah satu fashion hijab menjadi faktor pengaruh terjadinya perilaku konsumtif pada mahasiswi Fakultas Ekonomi dan Bisnis Islam IAIN Palangka Raya. Perilaku konsumtif mahasiswi ditunjukkan dengan hijab yang dikenakan pada saat di Kampus dengan berbagai gaya yang menjadi tren dan juga dari pertanyaan yang ada di item angket kebanyakan dari mahasiwi menjawab "saya selalu berbelanja sesuai keinginan" dan "saya akan membeli hijab dengan 2 atau 3 warna yang berbeda", hal ini menunjukkan bahwa mahasiswi akan membeli hijab bukan atas dasar kebutuhan namun keinginan yang akan menyebabkan pembelian hijab akan berlebihan. Pembelian yang berlebihan ini yang akan mengarah kepada perilaku konsumtif.

Hasil koefisien dibandingkan dengan interprestasi koefisien korelasi nilai r, maka 0,780 termasuk tingkat hubungan "kuat".Hal ini menunjukkan bahwa terjadi hubungan yang kuat antara fashion hijab dengan perilaku konsumtif.Hasil penelitian juga menunjukkan bahwa nilai $\mathrm{R}$ Square sebesar 0,609 yang dapat diartikan bahwa variabel fashion hijab mempunyai pengaruh sebesar $60,9 \%$ terhadap variabel perilaku konsumtif, sedangkan 39,1 lainnya dipengaruhi oleh faktor-faktor di luar dari variabel fashion hijab.

\section{Penutup}

Hasil analisis yang menggunakan teknik korelasi pearson product moment (r)menunjukkan bahwa korelasi antara Fashion hijab dengan perilaku konsumtif sebesar 0,780. Berdasarkan interprestasi koefisien korelasi nilai $r$, maka 0,780 termasuk tingkat hubungan "kuat". Hal ini menunjukkan bahwa terjadi hubungan yang kuat antara fashion hijab dengan perilaku konsumtif.Selain itu, signifikansi antara variabel fashion hijab (X) dan variabel perilaku konsumtif (Y) adalah sebesar 0,000. Berdasarkan kaidah keputusan dari 
ISSN : 2354-6034

IAIN Palangka Raya

hipotesis, nilai probabilitas 0,05 lebih besar atau sama dengan nilai probabilitas Sig. Atau ( $0,05 \geq 0,000$ ), maka Ho ditolak dan Ha diterima, artinya signifikan. Dan pengaruh fashion hijab terhadap perilaku konsumtif sebesar 60,9\%, sedangkan sisanya 39,1\% dipengaruhi oleh faktor lainnya.

\section{DAFTAR PUSTAKA}

Barnard, Malcolm, Fashion Sebagai Komunikasi: Cara Mengkomunikasikan Identitas Sosial, Seksual, Kelas Dan Gender, Yogyakarta: Jalasutra, 2011.

Departemen Agama RI, Al-Qur'an Dan Terjemahannya, Jakarta: Departemen Agama, 2000.

Fauzia, Ika Yunia, Prinsip dasar Ekonomi Islam Perspektif Maqashid Al-Syariah, Jakarta: Kencana, 2014.

Istiani, Ade Nur,Kontruksi Makna Hijab Fashion Bagi Moslem Fashion Blogger, http://jurnal.unpad.ac.id/jkk/article/.../3396, diakses pada tanggal 10 Maret 2016.

Jiha, Abi,Fiqih Shopping Jakarta: Zikrul Hakim, 2015.

Muhammad Muflih, Perilaku Konsumen Dalam Perspektif Ilmu Ekonomi Islam, Jakarta: PT RajaGrafindo Persada, 2006.

Riduwan dan Sunarto, Pengantar Statistika Untuk Penelitian: Pendidikan, Sosial, Komunikasi, Ekonomi, dan Bisnis, Bandung: Alfabeta, 2007.

Syahatah, Husein,Ekonomi Rumah Tangga Muslim, Jakarta: Gema Insani Press, 1998. 